\title{
PW02-017 - New tools for the ISSAID society website
}

\author{
I Touitou*, F Milhavet \\ From 7th Congress of International Society of Systemic Auto-Inflammatory Diseases (ISSAID) \\ Lausanne, Switerland. 22-26 May 2013
}

\section{Introduction}

The ISSAID (International Society for Systemic AutoInflammatory Diseases) born in November 2005, is supported by a website portal.

\section{Objectives}

The purpose of the website is to:

- gather resources related to the systemic autoinflammatory diseases in order to facilitate contacts between interested physicians and researchers.

- provide support to share and rapidly disseminate information, thoughts, feelings and experiences to improve the quality of life of patients and families affected by systemic auto-inflammatory diseases, and promote advances in the search for causes and cures.

\section{Methods}

Several existing items have been improved to provide extensive. Others have been developed. As decided at the last ISSAID council meeting in Amsterdam, access to specific sections of the ISSAID website is subjected to the payment of annual membership dues.

\section{Results}

Improved items

1. basic information

2. society missions and membership

3. previous and future meetings content

4. mutation and patient registries

5. image library showing characteristic physical features from patients suffering from AID

6. information related to laboratories such as quality control schemes for molecular diagnosis

7. useful links

Laboratoire de génétique des maladies rares et auto-inflammatoires, CHRU Montpellier, Montpellier Cedex 5, France

\section{New items}

We recently implemented a new "expert views" area with the possibility to

1. share professional experience

2. request expert advice

3. read updates on a specific topic, and research highlights

4. call for collaboration

\section{Conclusion}

We do believe that this relooked ISSAID website will further help disseminate information, promote advances in the search for the causes of AID, and improve the quality of life and cure of patients affected by AID.

\section{Disclosure of interest}

None declared.

Published: 8 November 2013

doi:10.1186/1546-0096-11-S1-A157

Cite this article as: Touitou and Milhavet: PW02-017 - New tools for the ISSAID society website. Pediatric Rheumatology 2013 11(Suppl 1):A157.

Submit your next manuscript to BioMed Central and take full advantage of:

- Convenient online submission

- Thorough peer review

- No space constraints or color figure charges

- Immediate publication on acceptance

- Inclusion in PubMed, CAS, Scopus and Google Scholar

- Research which is freely available for redistribution 